Carcass yield decreased with the energy concentration of the diet $(0.30$ point per $100 \mathrm{kcal} \mathrm{DE})$.

The gastrooesophageal mucosa was less affected by the low energy diets (barley) than by the other diets (maize and wheat). Nevertheless, maize appeared slightly more ulcerogenous than wheat.

\title{
General survey of the energy and protein value of French triticale
}

\author{
J.M. PEREZ, D. BOURDON
}

I.N.R.A., Station de Recherches Porcines, Saint-Gilles, 35590 L'Hermitage

Five digestibility experiments have been made since 1977 with the aim of determining the nutritive value of different triticale varieties for the pig, especially the Clercal variety selected by the I.N.R.A. A total of 32 Large White castrated male pigs were used distributed into eight groups of four pigs per diet and kept in individual pens specially equipped for digestive balance. After an adaptation period, excreta (faeces and urine) were collected for 10 consecutive days. The experimental diets only based on triticale (97 p. 100) were supplemented with minerals and vitamins. Eight triticale samples were tested.

According to the results obtained, the mean energy value (DE) of triticale for the pig was estimated at $3725( \pm 20) \mathrm{kcal} / \mathrm{kg} \mathrm{DM}$, i.e., half between that of rye $(3660 \mathrm{kcal})$ and wheat $(3830 \mathrm{kcal})$. The apparent digestibility of triticale proteins $(80.7 \mathrm{p} .100)$ was also half between the values obtained with these two cereals.

\section{Importance of cereal phytase activity for phytate phosphorus Utilization by growing pigs fed triticale or maize diets}

\author{
Annie FOURDIN, Nicole FONTAINE, A. POINTILLART \\ I.N.R.A., Station de Recherches de Nutrition, 78350 Jouy-en-Josas
}

In contrast to maize, triticale exhibits a high phytase activity. This dietary enzyme enhances phytic phosphorus digestibility as demonstrated in wheat fed pigs. To study phosphorus utilization, 12 growing pigs were fed either a maize (M) or a triticale (T) based diet for 6 weeks. Both diets exhibited the same energy, protein, vitamin D (1 $500 \mathrm{IU} / \mathrm{kg}$ diet $)$, calcium (0.5 p. 100$)$ and phosphorus $(0.4$ p. 100) content. No inorganic P was added to either diets. A 10-day balance study was carried out to estimate $\mathrm{Ca}$ and $\mathrm{P}$ absorption and retention.

Both diets caused a phosphorus deficiency, but hypophosphatemia occurred more rapidly while hypercalciura and hypophosphaturia were more marked with maize than with triticale. $\mathbf{P}$ absorption and retention were higher with $\mathrm{T}$ diet than with $\mathrm{M}$ diet : apparent absorption, $65 \pm 1$ vs $48 \pm 3$ p. 100 intake, respectively $(\mathbf{P}<0.01)$. This was probably related to the high phytase activity of triticale since phosphatase activities (phytase and alkaline phosphatase) of intestinal mucosa were similar in both groups of animals. Calcium absorption was not modified by the kind of cereal given, whereas Ca retention was greater on triticale than on maize diet. The higher mineral retention observed in triticale fed pigs led to significantly higher bone mineral contents. In addition, average daily gain and feed efficiency were significantly better in the triticale fed group. In conclusion, the higher the dietary phytase activity, the higher the phytate phosphorus availability. 